УАK 061.2(470+571)

ББK 66.7(2Pocc)

DOI 10.22394/1682-2358-2019-3-78-83

V.L. Temkin, post-graduate student of the Public Administration and National Security Department, Institute of Law and National Security, Russian Presidential Academy of National Economy and Public Administration

\section{DEVELOPMENT OF VOLUNTEER MOVEMENT IN MODERN RUSSIA}

The practical aspect of development of volunteer movement in Russia is considered. On the example of some organizations, theoretical generalizations are made. The importance of volunteer organizations' activity for the implementation of the state social policy is reflected.

Key words and word-combinations: volunteering, NCOs, civil society, social projects.

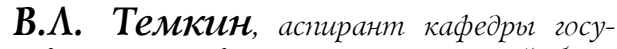
дарственного упраљления и начиональной безопасности Института права и национальной безопасности Российской академии народного хозяйства и государственной служббы при Президенme РФ (email: temkinmin@mail.ru)

\section{РАЗВИТИЕ ВОАОНТЕРСКОГО АВИЖЕНИЯ В СОВРЕМЕННОЙ РОССИИ}

\begin{abstract}
Аннотащия. Рассматривается практический аспект развития волонтерского движения в России. На примере некоторых организаций делаются теоретические обобщения. Отражено значение деятельности волонтерских организаций для реализации государственной социальной политики.

Ключевые слова и словосочетания: волонтерство, добровольчество, НКО, гражданское общество, социальные проекты.
\end{abstract}

\section{B}

олонтерское Авижение имеет широкое распространение в мире, явмяясь одним из показателей развития гражданского общества и социальной политики государства. В России Аобровольческое Авижение, с одной стороны, не имеет устоявшихся институџиональных и нормативных основ, с Аругой - практика реализации в некоторых организациях преАставляет практический и теоретический интерес как индикатор социальных проблем и потребностей общества, на которые реагируют Аобровольческие организации. Вопрос соџиальных потребностей, проблем мичности и общества всегда актуален, но в условиях современных реалий (пенсионная реформа, 
инфмяџия, огромный разрыв между бедными и богатыми, отсутствие как такового среднего класса) социальные проблемы ведут к социальным взрывам, что создает непосредственную угрозу наџиональной безопасности. Изучение опыта Аобровольческого Авижения России позволяет выявить характерные особенности такой деятельности в стране, а также определить практическую и теоретическую значимость вопросов реализации социальной политики государства и социальной ответственности общества, предупреждать и предотвращать негативные социальные явления, представцяющие угрозу национацьной безопасности. Объединение усилий государства и НКО в решении сощиальных проблем в настоящее время недостаточно и нуждается в более глубокой взаимной интеграции, что будет способствовать позитивным соџиальным изменениям.

Президент РФ В.В. Путин, подчеркивая значимость волонтерского Авижения, отметил, что во все времена представители разных сословий, возрастов, взглядов бескорыстно служили Отечеству, цюАям, активно участвоваци в делах просвещения и благотворительности, содействовали решению общественно значимых проблем в сфере образования, зАравоохранения, культуры, экологии. Он подчеркнул, что нельзя останавливаться на Аостигнутом, необходимо наращивать потенциал добровольческих организаций, расширять спектр их деятельности, активнее привлекать молодежкь [1] .

С.Г. Екамова отмечает, что активная вовлеченность студентов в волонтерскую деятельность способствует развитию таких мичностных и профессиональных качеств, как эмпатия, рефлективность и толерантность [2]. По мнению Ю.В. Паршиной, большинство подростков, занятых в волонтерском Авижкении, уже сделали свой выбор, они осознали, что в их силах сделать мир кучше [3] .

Термины «добровольчество» и «волонтерство» в современном понимании стали употребцяться в России к концу ХX в., но до неАавнего времени звучали Аовольно непривычно. В настоящее время ситуация меняется, Аанные понятия входят в жизнь, а само явление «благотворительность» становится понятным россиянам.

В начале 1990-х годов появимись первые некоммерческие организации, занимающиеся благотворительностью и просветительской Аеятельностью. Сегодня разцичные волонтерские программы позволяют АюАям участвовать в Аобровольческой деятельности и за рубежком, и в России [4]. Первые волонтерские ассоциации стали появцяться в России в начале нулевых. Некоторым удалось выйти на межкегиональный и фелеральный уровни. Вовлеченность в Аобровольческую деятельность не имеет религиозных, расовых, возрастных, гендерных или политических границ. Ежегодно в ряды волонтеров привлекаются мимиионы мюдей по всему миру [5; 6] .

В соответствии с Федеральным законом от 7 июля 1995 г. № 135-Ф3 «О благотворительной деятельности и добровольчестве (волонтерстве)» [7] под Аобровольческой (волонтерской) деятельностью понимается добровольная Аеятельность в форме безвозмезАного выполнения работ и (или) оказания услуг в общественно полезных целях. Закон уточняет, что направление денежных и Аругих материальных средств, оказание помощи в иных формах коммерческим организациям, а также поддержка политических партий, Авижений, групп и компаний благотворительной деятельностью не явцяются.

Вестник Поволжского института управления • 2019. Том 19. № 3 
Под участниками благотворительной деятельности понимаются граждане и юридические мица, осушествляющие благотворительную деятельность, в том числе через подАержку существуюшей или создание новой благотворительной организации, а также граждане и юридические миџа, в интересах которых осуществцяется благотворительная деятельность: бцаготворители, добровольџы (волонтеры), бцагополучатели. К участниками добровольческой (волонтерской) деятельности относятся добровольџы (волонтеры), организаторы добровольческой (волонтерской) деятельности и добровольческие (волонтерские) организации. Аобровольцы (волонтеры) - физические мица, осуществмяющие Аобровольческую (волонтерскую) деятельность.

Практика такова, что некоммерческая организация, как правило, не оформмяет отношения с Аобровольцами договором [8] . В России добровольцу выдается мичная книжка волонтера (паспорт) - не что иное, как своеобразный аналог трудовой книжки. В мичной книжке волонтера записываются данные о поощрениях, Аополнительной подготовке, а также сведения о волонтерском стаже.

В России на 2017 г., по данным Минюста, насчитывалось более 220 тыс. НКО [9], которые в той или иной форме занимаются волонтерской деятельностью. Рассмотрим примеры некоторых организаций.

Ассоциачия Волонтерских центров создана с џелью организации координации и подАержки волонтерских центров субъектов России. Миссией Ассоџиации является развитие Аобровольческого Авижения, распространение и культивирование ценностей добровольческого Авижения и соџиальной деятельности гражАан, содействие добровольцам в реализации мичностного и профессионального потенциалов. Цели Ассоџиаџии: вовлечение добровольцев в масштабные национальные проекты; содействие росту числа добровольческих инициатив и организаций, развитие культуры добровольчества, формирование инфраструктуры поддержки добровольчества в России [10]. Ассоџиаџией реализуются следующие проекты: ЕАиная информаџионная система «Аобровольџы России» (https://Аобровольцыроссии.рФ); Всероссийский конкурс «Аоброволещ

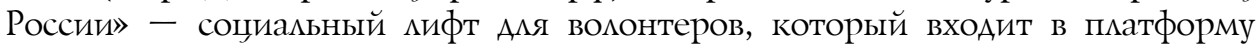
«Россия - страна возможностей» [11]. Комплексная программа «Ресурсные центры подлержкки добровольчества» направлена на создание эффективной инфраструктуры поддержкки добровольчества в регионах России, а также системы ее постоянного сопровождения [12]. В процессе реализации проекты: «Ты решаешь» [13] ; «Молоды Аушой» [14] ; «Узнай.PRO» [15] ; «Волонтеры мира» [16] .

Ассоџиация, имея сетевую структуру по всей России, имеет возможность Аовольно объективно оџенивать основные потребности соџиально незащищенных слоев населения, выявцять наиболее острые проблемы в этой сфере. Аанный потенциал целесообразно использовать в целях рациональной корректировки и определения векторального развития социальной политики.

Союз добровольцев России (САР) (Росволонтер) - всероссийская общественная организаџия, занимающаяся добровольческой (волонтерской деятельностью). САР реализует проекты в различных сферах: семья, материнство, детство; чрезвычайные ситуации; экология; работа с инвалидами; работа с сиротами; работа с ветеранами; работа с престарелыми гражданами; национамьная безопасность; спортивное волонтерство; межнациональные отношения. В 
Уставе САР обозначены следующие џели работы: развитие добровольчества в России, защита прав и свобод граждан, оказание помощи детям, инвалидам, пожилым АюАям и Аругим социально уязвимым слоям населения [17] .

Опыт работы САР позволяет не только использовать возможности Аобровольческой организации в решении соџиальных проблем, но и в вопросах Аиквидации последствий чрезвычайных ситуаций, контроля и мониторинга доступности среды (с последующей передачей результатов первым мицам субъектов), контроля исполнения соџиальных иниџиатив Президента РФ и Правительства РФ в регионах (Аобровольцы могут проводить негласный мониторинг реализаџии соџиальных инищиатив с последующей передачей информации интересантам), участия в обеспечении правопорядка.

Клуб «Соломон» организован по наџиональному признаку («Соломон» SOLOMON.help). Это светская организация на базе ФЕОР (Федерации еврейских общин России) - крупнейшей консолидированной еврейской организации в России, включающей более 170 еврейских общин в разных городах и регионах страны. В качестве девиза Клуб использует четыре глагола, побуждающих к действию: «Познавайте. Получайте. Используйте. Аарите». Помошь нуждающимся - один из столпов, на которые всегда опиралась еврейская община, и участники КАуба постоянно помогают Аюдям, которые оказались в сложной ситуации. Каждый член Клуба берет на себя благотворительные обязательства, которые идут в общее дело. КАуб реализует различные соџиальные проекты: «женский кАуб SOLOMON.help», «еврейский детский дом», «благотворительная кухня и столовая», «уход за больными и инвалидами», «голос Милосердия», «еврейская школа «Месивта».

Опыт работы Клуба «Соломон» представцяет собой яркий пример мокального объединения в цемях решения вопросов определенной соџиальной группы (своего рода прообраз местного самоуправления). Поддержка и стимулирование со стороны государства создания подобного рода объединений (по наџиональном, территориальному, возрастному, языковому и Аругим признакам) позволит решать множество проблем соџиального характера на цокальном уровне наиболее эффективными способами.

Представленные примеры характеризуют возможности и потенщиал НКО, занимающихся благотворительной и волонтерской деятельностью как партнеров государства в области соџиальной политики. Аеятельность НКО снижает уровень сощиальной напряженности в обществе, что, безусловно, положкительно сказывается на психологическом общественном сознании, способствует развитию гражданского общества, соџиально ответственного самосознания граждан, повышает авторитет страны в международных отношениях.

В результате анализа добровольческой деятельности указанных организаций выявлено, что их помощь сосредоточена на определенных категориях миџ и сферах, требующих поддержки и государства: пожилых мюАях; сиротах; инвалидах; материнстве и детстве; экологии; чрезвычайных ситуациях.

Необходимо отметить также активное участие волонтеров в крупных международных спортивных мероприятиях, К примеру, в Кубке конфедераций FIFA 2017 были заняты 5844 добровольца (Санкт-Петербург - 1733; Москва - 1590; Сочи - 1261; Казань -1260). Более 25000 волонтеров приняли 
участи в Олимпийских играх в Сочи [18]. Аобровольџы - это колоссальный ресурс Аля некоммерческих организаций, который характеризуется жеканием безвозмездного и качественного труда на благо общества [19] .

Меньшее число волонтеров в России, чем в западных странах, во многом связывают с тем, что благотворительность - обычное дело Аля многих семей в развитых государствах, где дети с малых мет оказывают посильную помощь старикам и инвалидам, нищим и бездомным, брошенным животным. По данным Росстата, среднегодовая численность добровольцев в России постоянно увеличивается (2014 г. - 2388 184, 2015 г. - 2492 974, 2016 г. - 2376 682, 2017 г. - 2731652 чел.) [20], при этом реальное количество участвующих в волонтерском движении гораздо больше за счет неучтенных мюдей. По мере расширения движения создается инфраструктура, развиваются новые техномогии Аля помощи добровольцам, увеличивается количество добровольческих проектов, выполненных совместно с государственными структурами. Регумярно проводятся конкурсы инициативных проектов, направленных на решение соџиальных проблем. Развитию движения способствуют интернет-технологии, добровольџы объединяются на онлайн-площадках дмя совместного оказания помощи и работы по разАичным направлениям: создаются группы, готовые прийти на помошь пострадавшим от природных стихийных бедствий, или мюАям, попавшим в сложные ситуации, инвалидам. Задействуются различные инструменты, чтобы рассказать о добровольческом движении, их мероприятиях и привлечь к Авижению молодежь. Задача максимум - сделать волонтерство нормой жизни, сформировать в АюАях привычку помогать Аруг Аругу [21] .

Выбор добровольцами объектов и направления деятельности, как правило, связан с социальными проблемами, в недостаточной мере или совсем не охваченными государственными или муниципальными ускугами. Государственнодобровольческое сотрудничество позволяет принимать оперативные и своевременные меры по решению и профилактике проблем в социальной сфере.

Особенностью Аобровольческого движения является его бескорыстность и глобально-локальная направленность, что выражается как в его распространении по всей территории государства, так и в возможности решать соџиальные пробкемы в малых населенных пунктах. Эта структура способна давать максимально объективные данные состояния соџиальной защищенности общества с минимальными затратами. Создание технической системы мониторинга, которая позволит отражкать реальную социальную картину, потребует существенных финансовых вможений и затрат времени, а также использования возможностей добровольческого Авижения. Существуюшая бюрократическая система органов власти, предоставляющая подобного рода информацию, сегодня не способна к объективной оџенке сложившейся в стране ситуации и требует реформирования.

Уровень развития волонтерского движения в стране в целом характеризует состояние общества: взаимоотношения общества и государства, морально-этические установки обшества, уровень правовой и трудовой свободы населения, степень удовлетворенности жизнью со стороны граждан. Симбиоз государства и НКО в соџиальной сфере, безусловно, окажет позитивное воздействие на улучшение соџиальной ситуации в России, выявит острые проблемы и приоритетные 
сферы дия государственного ияи общественного воздействия. По аналогии с госуАарственно-частным партнерством представляется возможным распространение в России государственно-некоммерческого партнерства, когАа НКО становятся офиџиальным партнером государства. В рамках такого сотрудничества часть функщий соџиальной направленности может быть передана в соответствии с Аоговором в некоммерческие организации. Разумеется, это приведет к необходимости разработки соответствующих нормативно-правовых актов, например, Федерального закона «О государственно-некоммерческом партнерстве».

Использование государством возможностей некоммерческих организаџий, их партнерские отношения преАставмяются необходимыми могичной, объективной и экономической мерами на фоне кризисных проявлений в экономике, коррупџионных скандалов в органах вмасти и затянутости принятия и реализаџии решений органами власти.

\section{Библиографический список}

1. Владимир Путин призвал волонтеров расширить спектр деятельности. URL: https:// rg.ru/amp/2015/02/13/volonteri-site-anons.html

2. Екимова С.Г. Волонтерская деятельность как ресурс личностно-профессионального развития будущих специалистов по социальной работе: автореф. дис. ... канд. пед. наук. Хабаровск, 2010.

3. Паршина Ю.В. Волонтерское движение и его истоки в России // Известия ВГПУ. 2009. № 9. C. 106-109.

4. Интересно о волонтерстве. URL: https://rgup.ru/?mod=pages\&id=703

5. Общешкольное родительское собрание по теме: «Волонтеры». URL: https://infourok.ru/ obscheshkolnoe-roditelskoe-sobranie-po-teme-volonteri-2762838.html

6. Библиотека Горького. URL: https://www.gorkilib.ru/events/otkryta-vystavka-2018-goddobrovoltsa-volontera-

7. Российская газета. Федер. вып. 2018.7 февр., № 7489 (26).

8. Труд волонтера в некоммерческих организациях. URL: http://pravo-zoozahita.ru/trudvolonterov-v-nekommercheskix-organizaciyax/

9. Минюст: общее число НКО в России стабильно. URL: https://regnum.ru/news/2348150.html

10. Ассоциация волонтерских центров. URL: http://авц.pф

11. Всероссийский конкурс «Доброволец России». URL: https:// добровольцыроссии.pф/ contests/2018/dobrovolec

12. Ресурсные центры поддержки добровольчества. URL: http://авц.pф/resources

13. Ты решаешь. URL: http://авц.pф/todo/youmake

14. Молоды душой. URL: http://авц.pф/todo/youngsoul

15. Узнай. PRO. URL: https://http://обучение.добровольцыроссии.рф

16. Волонтеры Мира. URL: http://авц.pф/vlrworld

17. Союз добровольцев России. URL: http://www.souzdobro.ru/about/statute/

18. Волонтерство. URL: http://www.wikiwand.com/ru/Волонтерство

19. Перспективы волонтерского движения. URL: https://studbooks.net/631062/sotsiologiya/ perspektivy_volonterskogo_dvizheniya

20. Аналитический центр при Правительстве РФ. Доклад «О проведении научных, социологических и статистических исследований, направленных на изучение форм и масштабов участия граждан и организаций в добровольческой (волонтерской) деятельности». URL: http:// ac.gov.ru/files/publication/a/21338.pdf

21. Волонтерское движение в России. Кто такие волонтеры? URL: http://forum-msk.info/ threads/volonterskoe-dvizhenie-v-rossii-kto-takie-volontery.3161/

Вестник Поволжского института управления • 2019. Том 19. № 3 